\title{
Gretchen Mieszkowski, Medieval Go-Betweens and Chaucer's Pandarus
}

\section{G. Matteo Roccati}

\section{Q OpenEdition}

10 Journals

\section{Édition électronique}

URL : http://journals.openedition.org/studifrancesi/8822

DOI : 10.4000/studifrancesi.8822

ISSN : 2421-5856

Éditeur

Rosenberg \& Sellier

\section{Édition imprimée}

Date de publication : 1 octobre 2008

Pagination : 429

ISSN : 0039-2944

\section{Référence électronique}

G. Matteo Roccati, « Gretchen Mieszkowski, Medieval Go-Betweens and Chaucer's Pandarus », Studi Francesi [En ligne], 155 (LII | II) | 2008, mis en ligne le 30 novembre 2015, consulté le 13 janvier 2021. URL : http://journals.openedition.org/studifrancesi/8822 ; DOI : https://doi.org/10.4000/studifrancesi. 8822

Ce document a été généré automatiquement le 13 janvier 2021.

\section{(c)}

Studi Francesi è distribuita con Licenza Creative Commons Attribuzione - Non commerciale - Non opere derivate 4.0 Internazionale. 


\title{
Gretchen Mieszkowski, Medieval Go- Betweens and Chaucer's Pandarus
}

\author{
G. Matteo Roccati
}

\section{RÉFÉRENCE}

GRETCHEN MIESZKOWSKI, Medieval Go-Betweens and Chaucer's Pandarus, New York, Palgrave MacMillan, 2006 («The New Middle Ages»), pp. X-218.

L'A. étudie les traditions littéraires dans lesquelles s'enracine le personnage de Pandarus, l'ami qui seconde la passion des deux amants dans Troilus et Criseyde de Chaucer. Il examine la figure de l'entre-metteur (-euse) dans de nombreux textes du XII ${ }^{\mathrm{e}}$ $\mathrm{au} \mathrm{XV}^{\mathrm{e}}$ siècles: comédies élégiaques, fabliaux, romans. Les trois parties dans lesquelles l'ouvrage est organisé sont consacrées respectivement à cette figure, dans sa forme "brute" d'adjuvant dans la conquête sexuelle (notamment la Vieille du Roman de la rose), dans sa forme idéalisée d'ami ou confident qui œuvre non pour forcer l'aimée, mais contre les instances hostiles à l'amour (Guenièvre dans Cligés, Alexandrine dans Guillaume de Palerne, Galehot, etc.) enfin à Chaucer, qui croise ces deux figures appartenant à des traditions idéologiquement antithétiques. La bibliographie (pp. 203-212) et l'index (noms et notions, pp. 213-218) complètent le volume. 